\title{
A Study on the Talents Predicament and Countermeasure of Rural Revitalization
}

\author{
Tingyan $\mathrm{Bi}^{1}{ }^{1, a}$, Jinling $\mathrm{Han}^{2, \mathrm{~b}^{*}}$ \\ ${ }^{1}$ Institute of Higher Education, Weifang University, Weifang China \\ 2 Labour Union, Weifang University, Weifang China \\ abtylook@163.com, bb8877208@163.com \\ ${ }^{*}$ Corresponding author
}

Keywords: Rural Revitalization, Talent Revitalization, Talent, Rural Areas.

\begin{abstract}
The key to the Rural Revitalization lies in the talent revitalization. With the in-depth implementation of the strategy of rural revitalization, to a great extent a series of deep-seated rural farmers'agricultural problems have been effectively solved. China is getting closer and closer to the goal of "strong agriculture, beautiful countryside and rich farmers". But we should also see that the plight of talent shortage has been shackling the process of talent revitalization. To get out of the dilemma of talent shortage and realize talent revitalization, the government should make reasonable institutional arrangements, create a good humanistic environment in the countryside, being effective in training talents of Colleges and universities, and stimulate the endogenous motive force of villagers'participation in talent revitalization.
\end{abstract}

\section{乡村振兴的人才困境与对策研究 \\ 毕廷延 $1, a$, 韩金玲 $2, \mathrm{~b},{ }^{*}$ \\ 1淮坊学院高教研究所, 潍坊, 中国 \\ 2淮坊学院工会, 潍坊, 中国 \\ abtylook@163.com, bb8877208@163.com \\ “通讯作者}

关键词：乡村振兴；人才振兴；人才；农村

中文摘要. 随着乡村振兴战略的深入实施，一系列深层次的农业农村农民问题在很大程度上 得到有效解决, 我国距离实现 “农业强、农村美、农民富” 的目标越来越近。但也应当看到, 人才短缺的困境一直桎梏着人才振兴的进程。乡村振兴, 关键在人才振兴。走出人才短缺的 现实困境, 真正实现人才振兴, 政府要做好合理的制度安排, 乡村要营造良好的人文环境, 高校要发挥培养人才的作用，还要激发乡民参与人才振兴的内生动力。

\section{1. 引言}

我国是一个人口大国、农业大国，农民占比仍然较高。农业农村农民问题，是关系国计 民生的根本性问题。习近平关于农业农村农民问题的系列重要讲话,充分体现了他对“三农”工 作的新理念新思想新战略, 是新时代中国特色社会主义思想的重要组成部分。由于发展历程 中诸多因素的影响，使得我国城乡之间的发展存在不平衡性，农村发展存在不充分性。实施 乡村振兴战略,是缩小城乡差距、实现农村充分发展的重要举措。习近平指出:“中国要强农业 
必须强, 中国要美农村必须美, 中国要富农民必须富。”他多次强调: “要培养本地人才, 引 导广大村民学文化、学技能, 提高本领, 还要移风易俗, 通过辛勤劳动脱贫致富。”在实施乡 村产业、人才、文化、生态和组织“五大振兴”中，人才振兴是关键。实施人才振兴战略，发 展特色农村产业，实现农民长期稳定致富，实现“农业强、农村美、农民富”的奋斗目标，关 键是要培养造就一支高素质的人才队伍, 补齐人才不足的短板。

\section{2. 乡村振兴的关键是人才振兴}

实现人才振兴, 重在实干、抓在落实。马克思在《哥达纲领批判》中指出: “一步实际行 动胜过一打纲领。”意思是说, 不管做什么事情, 重在实际行动, 不做表面文章、纸上谈兵, 不做说话的巨人、行动的矮子。重实干、抓落实, 是马克思主义者的鲜明品格, 也是指导我 们实施乡村振兴战略的思想基础和行动指南。中国几代中央领导人都十分重视实干、抓落实。 毛泽东十分重视实干精神。1919年, 毛泽东在《湘江评论》的创刊词中写道: “天下者, 我们 的天下; 国家者, 我们的国家; 社会者, 我们的社会。我们不说, 谁说? 我们不干, 谁干? ” 在担任党内领袖后, 他指出: “什么东西只有抓得很紧, 毫不放松, 才能抓住。抓而不紧, 等 于不抓。”这为我们做好各项工作指明了方向、提供了方法论。邓小平重视实干精神, 他指出: “世界上的事情都是干出来的, 不干, 半点马克思主义也没有”，他多次强调要“少说空话、多 干实事”。江泽民重视抓落实, 他告诫全党: “要落实、落实、再落实, 因为这是做好一切工 作的关键环节。”胡锦涛强调抓落实, 他指出: “我们必须从党的路线方针政策全面贯彻执行、 确保党和国家发展目标顺利实现的高度，把抓落实问题十分严肃地提到全党面前。扎扎实实 地把党和国家的各项决策落到实处。”习近平一直重视真抓实干，他多次强调“一分部署九分 落实”的重要性，他把抓落实上升到对干部“以事识德”的高度。“抓落实的工作实践检验着领 导干部的思想品质、工作作风和实际能力, 也是考察和选用干部的重要依据”。在2017年初召 开的十八届中央纪委七次全会上, 习近平提出, 要“内化于心提高认识 外化于行狠抓落实”。 要“既当改革促进派又当改革实干家，盯住干、马上办”。

\section{3.人才振兴面临的现实困境}

实施乡村振兴战略是一个系统工程，不可能一䟣而就，必须坚持规划先行，破除人才瓶 颈，实现人才振兴。当前我国农村基础设施投入较大，基本实现了“五通”“十有”，但农村人 居环境改善仍然面临较大短板, 公共配套服务水平较低, 与城镇相比还有较大差距, 不能满足 农民对美好生活的需要。农村教育的有效供给侧严重不足, 农村劳动力市场配置滞后, 返乡 农民工面临诸如市场、财税、金融和土地等要素的约束。所有这些问题都说明，目前的农村 现状距离“让农业成为有奔头的产业，让农民成为有吸引力的职业，让农村成为安居乐业的家 园”的要求还有不小的距离。“农村居民人均可支配收入与城市居民收入差距依然较大。”[1]农 民返乡创业面临的问题也不少，在农村“扩大农业经营规模、提高农业劳动生产率受到制约。”[2] 随着农业政策的不断完善, 农民返乡创业的意愿不断增强, 但问题是农村缺乏帮助返乡农民 创新创业的生态环境和人文环境，这其中包括制度层面的合理安排。目前农村存在的问题是 多方面的、深层次的，随着乡村融合发展趋势的发展，“乡村基层仍存在一些深层次问题，制 约着乡村人力资本的积累、配置和效能发挥。”[3]农民对不坚持“量力而行、量入为出”原则地 大拆大建，村庄建设的盲目投资，对村集体负债过高现状的担忧不是多余的。调查发现“有的 地方村均负债数百万元, 且越是“明星村” “典型村”, 债务越重。而具有隐蔽性、私人性特点的 村债，往往‘旧的未消、新的又来’，极易引发治理风险，冲击乡村振兴。”[4] 


\section{4. 实现人才振兴的对策建议}

应该看到，实现人才振兴，是一项长期而艰巨的任务，也是一项不得不做的工作。实现 人才振兴的路径很多, 不拘一格。不管是什么样的发展路径, 有效就行。笔者认为, 实现人 才振兴，可以从政府、乡村、高校、乡民四个层面对症施策。

\section{1 政府要做好人才振兴的制度安排}

习近平提出, 要创新乡村人才工作体制机制, 充分激发乡村现有人才活力, 把更多城市 人才引向乡村创新创业。实现人才振兴, 各级党委政府都应因地制宜、因村制宜、因人制宜, 根据不同乡村的实际情况，制定相应的配套政策，完善相应的体制机制。山东省印发了《山 东省乡村振兴战略规划（2018-2022年）》, 又相继出台了包括人才振兴在内的系列工作方案, 为顺利实施乡村振兴战略规划做好了顶层设计和制度安排。山东省委制定出台的《关于进一 步激励广大干部新时代新担当新作为的实施意见》, 明确了 22 条实施意见激励干部担当作为。 教育部印发的《高等学校乡村振兴科技创新行动计划（2018-2022年）》，强化高校科技和 人才支撑体系, 引导高校师生关注乡村振兴, “把论文写在祖国大地上”, 旨在提升高校服务 乡村振兴的能力和水平。政协委员的呼吁，得到了社会各界的广泛关注和积极回应，一系列 有利于人才振兴的新的人才政策有望在不久的将来应运而生。

\section{2 乡村要营造人才振兴的人文环境}

习近平指出，要激励各类人才在农村广阔天地大施所能、大展才华、大显身手，打造一 支强大的乡村振兴人才队伍。乡村振兴“让年轻人成长为村里的干部, 既要有岗位吸引, 也要 有待遇保障, 要留人又留心，完善村干部队伍。”[5]实现人才振兴，要注意引导各类人才投身 乡村建设, 完善舆论和人文环境, 吸引大学生、进城务工人员、退伍军人返乡创业。要优化 农村人文环境, 吸引城市专业人才, 鼓励人才在乡村振兴中施展才华, 实现人生价值。乡村 居民的素质决定着乡村文化的质量、水平和特色, 要重视乡土专业人才培养, 加强乡土文化、 农耕文化建设。很多农村结合自身区位优势、产业优势，大打民俗游品牌，这样做的初衷无 可厚非，但要“以家庭农场主、新型职业农民、乡村旅游合作社成员、返乡创业人员等为重点 对象, 加强乡土专业人才培养, 切实提高乡村旅游的服务质量和经营水平, 更好满足游客的 需求。”[6]

\section{3 高校要发挥培养人才的重要作用}

人才振兴, 教育先行。高校在乡村振兴的作用不容忽视, 特别是在师资教育和培训方面 的优势得天独厚。“人才资源是第一资源。建设人力资源强国,需要大批高素质的人才。培育 高层次人才,离不开高校。”[7]地方高校要“注重教师发展培训，为教师终身发展提供机会和平 台。”[8]让优秀的教师能力来农村教学, 使他们进得来、留得住、发展好。适应乡村振兴战略 对应用型人才培养的需要,地方高校向应用型转变是大势所趋, “地方高校综合改革既要尊重 高等教育规律，又要从高校实际出发把握好“度”。”[9]“应用型高校以服务区域发展和产业振兴 为主要目标, 承担着培养应用型技术技能人才、增强学生就业创业能力、强化高校应用技术 创新驱动发展能力等重要职责。”[10]要通过深化综合改革, 重新定位高校的培养目标和人才培 养规格。“培养目标是人才培养的根本依据,是高校培养人才的价值导向和具体要求。培养规 格是培养目标的细化和具体化, 是根据培养目标的总体要求, 结合专业实际设定的具体的培 养目标。”[11]总之，应用型高校的一项重要使命，就是要通过多种渠道、采取多种方式方法， 为实施乡村振兴战略培养一大批高素质的应用型人才。

\section{4 要激发乡民参与人才振兴的内生动力}

在事物的发展变化过程中，内因起着决定性的作用。乡村振兴，乡民是主要力量。习近 平指出, 要积极培养本土人才, 鼓励外出能人返乡创业, 鼓励大学生村官扎根基层, 为乡村 
振兴提供人才保障。真正提高乡村治理的现代化水平，关键在于激发作为乡村振兴主体一 乡民的内生动力。市场经济条件下，乡村振兴推动城乡人才资源双向流动，农村农业环境的 实际决定着乡村人才的去留。乡贤在乡村振兴中的作用不可小觑，见识广、财力大、资源多、 乐奉献的乡贤是推动乡村振兴的“潜在”人才队伍。随着乡村基础设施条件的不断完善，老百 姓的物质生活得到较大改善，但保持乡村可持续平稳发展，需要德才兼备的乡民“冒”出来、 返回来、招回来。基层党组织的一项重要工作，就是要通过组织乡民进行系统的培训学习, 提高他们的思想政治觉悟、政策理论水平和参与乡村振兴的能力; 通过营造创新创业的良好 氛围, 为他们提供在乡村振兴道路上展现才华的平台; 通过调动乡民干事创业的积极性、主 动性，激发他们参与乡村振兴的内生动力。

\section{References}

[1] Li AImin. The Process, Problems and Path of Urban-Rural Integration Development in China[J]. Macroeconomic Research, Vol.2, pp.38, 2019.

[2] Zhang Xiaoshan. Promoting Agricultural Modernization Faces New Situation and New Tasks[N]. People's Daily, 2019-05-13(9).

[3] Lai Desheng, Chen Jianwei. Human Capital and Rural Revitalization[J]. Social Sciences in Chinese Colleges and Universities, Vol.6, pp.21, 2018.

[4] Liang Xiaofei, Liu Liangheng. The more "Star Village" is in debt, the more serious? Watch out for the Risk of Village Debt and Shock the Vitalization of Rural Areas[J]. Comment,Vol.9, 2019.

[5] Yang Wenming. Villages should be rejuvenated and attention should be paid to the training of young village officials[N]. People's Daily, 2019-04-18(5).

[6] Zhao Hang. Make good use of rural natural resources and human resources to make rural tourism better help rural revitalization[N]. People's Daily, 2019-04-09(9).

[7] Bi Tingyan. Research on the Effectiveness of Human Resources Management in Colleges and Universities and Its Countermeasure[A]. Conference Papers Collection of Intelligent Information Technology Applied Society[C]. Proceedings of 2013 International Conference on Management Innovation and Business Innovation(ICMIBI 2013, V.16), Singapore, 2013-04-21.

[8] Ke Jin. To promote rural revitalization, first of all, we should vigorously promote the revitalization of rural education[N]. China Education Daily, 2019-03-11(2).

[9] Feng Binlu, Bi Tingyan.Deepening the Comprehensive Reform of Higher Education and Promoting the Transitional Development of Local Universities[J]. Chinese Journal of Higher Education, Vol.10, pp.34-36, 2019.

[10]Zhang Wenzhi, Zhang Fuguo. Four Fulcrums of the Construction of Think Tanks in Applied Universities[N]. Guangming Daily, 2019-06-10(16).

[11]Feng Binlu, Bi Tingyan and Wei Chenming.Talents Training Specifications of Applied Undergraduate Colleges and Universities[J]. Shandong Journal of Higher Education, Vol.2, pp.48-53, 2019. 